\title{
ANALISIS KADAR PATCHOULI ALCOHOL MENGGUNAKAN GAS CHROMATOGRAPHY-MASS SPECTROMETRY (GC-MS) PADA PEMURNIAN MINYAK NILAM (Pogostemon cablin B.) ACEH TAMIANG DENGAN NANOMONTMORILLONITE
}

\author{
DEVI RAMAYANTI ${ }^{1}$, TISNA HARMAWAN ${ }^{1}{ }^{*}$, DAN RAHMATUL FAJRI ${ }^{1}$ \\ ${ }^{1}$ Departemen Kimia, Fakultas Teknik, Universitas Samudra \\ Jalan Prof. Dr. Syarief Tayeb, Langsa, Aceh, Indonesia. \\ *alamat email korespondensi: tisna_harmawan@unsam.ac.id
}

\begin{tabular}{l} 
Informasi Artikel \\
\hline Riwayat Naskah : \\
Diterima pada 29 \\
September 2021 \\
Diterima setelah \\
direvisi pada 27 \\
Desember 2021 \\
Diterbitkan pada 31 \\
Desember 2021
\end{tabular}

Kata Kunci: Minyak nilam; Kadar PA;NanoMMT.

Keywords: Patchouli oil; Patchouli Alcohol; Nano-MMT.

\begin{abstract}
Abstrak/Abstract
Tanaman nilam (Pogostemon cablin Benth.) merupakan salah satu tanaman penghasil minyak atsiri atau yang lebih dikenal dengan nama Patchouli Alcohol (PA). PA merupakan senyawa yang terbesar di dalam minyak nilam sebagai penentu mutu minyak nilam, kadar PA dalam minyak nilam menurut SNI 06-2385-2006 yaitu minimal 30\%. Sampel minyak nilam yang digunakan adalah minyak nilam yang berasal dari Aceh Tamiang. Tujuan penelitian ini dilakukan untuk mengetahui kadar PA sebelum dan sesudah adsorbsi menggunakan Nanomontmorillonite (Nano-MMT) sebagai adsorben dengan menggunakan metode kualitatif dengan uji warna dan metode kuantitatif dengan analisis Gas Cromatography Mass Spectrometry (GC-MS) untuk menentukan kadar PA, mengingat Nano-MMT adalah jenis tanah liat (clay) yang dapat digunakan sebagai adsorben yang mengadsorpsi kontaminan metalik dengan baik dikarenakan Nano-MMT mempunyai muatan negatif yang dapat mengikat spesies yang bermuatan positif kontaminan metalik seperti logam berat. Berdasarkan hasil analisis diketahui bahwa kadar PA sebelum diadsorpsi 7,74\% b/v, dan kadar PA setelah diadsorpsi berkisar antara 4,47\%-7,86\% b/v, kadar tersebut belum sesuai dengan SNI. Hal ini disebabkan karena banyak hal diantaranya terdapat komponen pengotor berupa kontaminan metalik seperti logam, terjadinya oksidasi, tercampurnya minyak nilam dengan bahan lain, pencemaran wadah penyulingan minyak, dan waktu penyimpanan yang relatif lama.
\end{abstract}

\begin{abstract}
Patchouli (Pogostemon cablin Benth) is a plant that produces essential oils or better known as Patchouli Alcohol (PA). PA is the largest compound in patchouli oil as a determinant of the quality of patchouli oil, the level of PA in patchouli oil according to SNI 06-2385-2006 is at least 30\%. The patchouli oil sample used was patchouli oil from Aceh Tamiang. The purpose of this study was to determine PA levels before and after adsorption using Nanomontmorillonite (Nano-MMT) as an adsorbent by using qualitative methods with color testing and quantitative methods with Gas Chromatography Mass Spectrometry (GC-MS) analysis to determine Patchouli Alcohol (PA), considering that Nano-MMT is a type of clay which can be used as an adsorbent which adsorbs metallic contaminants well because NanoMMT has a negative charge which can bind positively charged species of metallic contaminants such as heavy metals. Based on the results of the analysis, it is known that the level of PA before adsorption is $7.74 \% \mathrm{w} / \mathrm{v}$, and the level of PA after being adsorbed ranges from $4.47 \%-7.86 \% \mathrm{w} / \mathrm{v}$, these levels are not in accordance with SNI. This is due to many things including impurities in the form of metallic contaminants such as metal, oxidation, mixing of patchouli oil with other materials, contamination of oil refining containers, and relatively long storage time.
\end{abstract}

\section{PENDAHULUAN}

Minyak atsiri atau disebut juga dengan essential oil, etherial oils, atau volatile oils adalah komoditi ekstrak alami jenis tumbuhan yang berasal dari daun, bunga, kayu, biji-bijian bahkan putik bunga [1]. Minyak atsiri sebagian besar diambil dari berbagai jenis tanaman penghasil minyak atsiri, salah satunyaadalah minyak nilam (Pogostemon cablin Benth.) [2].
Salah satu penghasil minyak nilam yang terbesar di Indonesia adalah provinsi Aceh. Menurut Data Statistik Perkebunan Indonesia Komoditas Nilam 2017, Aceh memiliki luas areal perkebunan sebesar $2.498 \mathrm{Ha}$ dan memproduksi sebanyak 645 ton nilam, sedangkan menurut Data Statistik Perkebunan Indonesia Komoditas Nilam 2015, di daerah Aceh Tamiang mempunyai areal perkebunan seluas $3 \mathrm{Ha}$ dan memproduksi sebanyak 1 ton nilam. Nilam yang umum dibudidayakan 
petani adalah nilam Aceh (Pogostemon cablin Benth.) karena kadar minyaknya lebih tinggi dari nilam Jawa (Pogostemon heyneanus Benth.) [3]. Minyak nilam merupakan minyak atsiri yang diperoleh dari hasil penyulingan daun, batang dan cabang tanaman nilam [4]. Pogostemon cablin Benth. merupakan salah satu tanaman penghasil minyak atsiri yang cukup penting, dan dikenal dengan nama Patchouli Oil. Tanaman ini mengandung komponen utama Patchouli Alcohol (PA), yaitu suatu senyawa kelompok seskuiterpen dengan rumus molekul $\mathrm{C}_{15} \mathrm{H}_{26} \mathrm{O}$ [5].

Kadar PA merupakan salah satu parameter yang menentukan kualitas minyak nilam yang baik. Semakin tinggi kadar PA maka kualitasnya semakin baik dan kadar PA itu sendiri sangat menentukan harga minyak nilam, dimana semakin tinggi kadar PA maka harga jualnya akan meningkat. Menurut SNI 06-2385-2006, kadar PA dalam minyak nilam minimal 30\%. Di Indonesia, masih banyak ditemui minyak nilam mempunyai kadar PA dibawah $30 \%$ [6]. Hal ini akan mengakibatkan rendahnya mutu atau kualitas, harga dan tidak memenuhi persyaratan yang ditentukan oleh pasar dunia sehingga harga jualnya relatif rendah. Proses atau metode penyulingan yang sering dipakai oleh masyarakat masih sangat tradisional, salah satunya dengan penggunaan wadah besi. Wadah besi merupakan salah satu penyebab ion logam terlarut seperti besi, magnesium, mangan, tembaga, dan seng yang membuat minyak nilam berwarna coklat tua dan menurunkan kualitas.

Peningkatan kualitas minyak nilam pasca penyulingan dapat menggunakan metode adsorpsi yang digunakan sebagai salah satu alternatif perbaikan mutu minyak nilam. Teknik adsorpsi merupakan proses difusi komponen pada permukaan atau antara partikel yang mengikat permukaan adsorben dengan adsorbat atom, ion, atau molekul yang melibatkan ikatan intramolekul di antara mereka [7]. Adsorpsi minyak nilam dapat dilakukan dengan menggunakan adsorben montmorillonit (MMT). Penggunaan MMT dipilih karena sifatnya dan kapasitas penyerapannya dipengaruhi oleh adanya ruang pori antara ikatan mineral lempung serta ketidakseimbangan muatan listrik dalam ion,

MMT merupakan salah satu jenis lempung smektit yang paling banyak digunakan dalam komposit polimer nanofiller. Perhatian khusus telah diberikan pada mineral Nano-MMT karena ukurannya yang kecil, dan area permukaan dari Nano-MMT yang sangat besar serta sifat pengelupasan dan interkalasi [8] [9].

Beberapa penelitian sebelumnya telah dilakukan, tentang peningkatan kualitas minyak nilam dengan adsorben karbon aktif dan MMT melalui beberapa proses diantaranya pengkhelatan, dan pengaruh $\mathrm{pH}$. Proses perlakuan perbedaan dari $\mathrm{Ph}$ memberikan hasil yang sesuai dengan Standar Nasional Indonesia [10]. Pada penelitian lain telah dilakukan tentang pemurnian minyak nilam menggunakan adsorben zeolit dan memberikan hasil tidak sesuai yang dipersyaratkan Standar Nasional Indonesia [11].

Berdasarkan latar belakang tersebut dilakukan penelitian untuk menganalisis kualitas minyak nilam meliputi kadar dari PA pada minyak nilam Aceh Tamiang, kemudian digunakan NanoMMT sebagai adsorben untuk meningkatkan kualitas minyak nilam karena ukuran partikel yang lebih kecil dan memperbesar luas permukaan sehingga daya adsorpsi lebih tinggi dan menggunakan metode kualitatif dengan uji warna dan metode kuantitatif dengan analisis Gas Cromatography Mass Spectrometry (GC-MS). Sebagai referensi untuk standar kualitas minyak nilam peneliti menggunakan Standar Nasional Indonesia nomor 06-2386-2006 pada tahun 2006 tentang kualitas minyak nilam.

\section{EKSPERIMEN}

Metode yang digunakan dalam penelitian ini adalah mixed-methode, metode kualitatif dengan uji warna dan metode kuantitatif dengan analisis Gas Cromatography Mass Spectrometry (GC-MS). Metode pengumpulan data menggunakan metode eksperimen untuk menganalisis minyak nilam sebelum dan sesudah diperlakukan dengan NanoMMT.

\section{Material}

Bahan yang digunakan dalam penelitian ini adalah akuades dan bentonit. Sampel yang digunakan dalam penelitian ini adalah minyak nilam dari Aceh Tamiang.

\section{Instrumentasi}

Adapun instrumentasi yang digunakan meliputi seperangkat alat Ultrasonic Batch, High Energy Milling (HEM) SPEX CertiPep $8000 \mathrm{M}$, Particle Size Analyzer (PSA) SZ-100 (Horiba Scientific), X-Ray Diffraction (XRD) 6000 (Shimadzu) dan Gas Cromatography Mass Spectrometry (GC-MS) YL 6900 (Shimadzu).

\section{Prosedur}

Preparasi Batuan Bentonit Menjadi Montmorilonit

Bentonit ditumbuk hingga halus dan disaring dengan ayakan 250 mesh. Ditimbang sebanyak $50 \mathrm{~g}$ 
dan dimasukkan ke dalam ultrasonic batch yang telah diisi dengan $2 \mathrm{~L}$ akuades, dan diberikan gelombang 70elative70s selama 15 menit. Diambil endapannya, endapan ini dinamakan Fraksi 1. Filtrat diaduk sebanyak 10 kali didiamkan selama 3 hari dan diambil endapannya, endapannya dinamakan dengan Fraksi 2. Selanjutnya 70elative diaduk sebanyak 10 kali adukan, didiamkan selama 7 hari dan diambil endapannya, endapannya dinamakan dengan Fraksi 3. Filtratnya diuapkan untuk menghilangkan kadar air seluruhnya (Fraksi 4) $[12][13]$.

\section{Pembuatan Nanomontmorilonite}

MMT ditumbuk dengan alat HEM selama 30 Jam kemudian dianalisis dengan XRD dan PSA untuk membuktikan bahwa MMT telah berukuran nano.

\section{Pemurnian Minyak Nilam Menggunakan Nanomontmorilonite}

Minyak nilam $10 \mathrm{~mL}$ diambil gambarnya untuk mengetahui warna awal dan dianalisis GCMS sebelum diadsorpsi. Kemudian minyak nilam diadsorpsi menggunakan Nano-MMT sebanyak $1 \mathrm{~g}$. Pengadukan dilakukan selama 2 jam sampai NanoMMT tercampur dalam minyak nilam. Setelah tercampur, larutan disaring dan dimasukkan ke dalam gelas kimia. Filtrat minyak nilam diambil gambarnya lagi untuk mengetahui perubahan warna setelah diadsorpsi menggunakan Nano-MMT, 70elative dipindahkan ke dalam botol vial dan sampel siap dianalisa GC-MS [11]. Dilakukan hal yang sama untuk konsentrasi perbandingan $(\mathrm{b} / \mathrm{v}) 10$ : 0,$5 ; 10: 1 ; 10: 1,5 ; 10: 2 ; 10: 2,5 ;$ dan $10: 3$.

\section{HASIL DAN PEMBAHASAN}

\section{Karakterisasi Montmorillonit dari Bentonit Alam Aceh Tamiang}

MMT telah diisolasi dari bentonit alam Aceh Tamiang, MMT tersebut kemudian diproses menjadi Nano-MMT dengan metode HEM. Hasil dari isolasi bentonit menjadi Nano-MMT dapat dilihat pada Gambar 1.

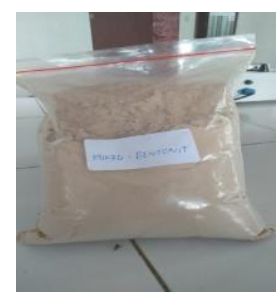

a

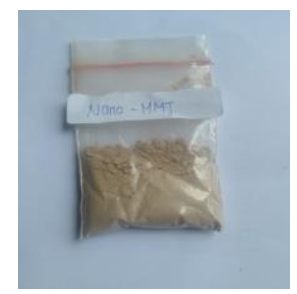

b
Gambar 1. a) Bentonit aceh tamiang, b) Nano- MMT.

\section{Karakterisasi Menggunakan XRD (X-Ray Diffraction)}

Teknik XRD merupakan teknik umum yang dipakai untuk mengetahui karakteristik suatu material seperti ukuran, butir, unsur dan parameter kisi dari suatu kristal melalui puncak-puncak intensitas yang muncul [14]. Sumbu X menunjukkan sudut pergerakan $2 \theta$ dengan sudut pergerakan $0,01^{\circ}$ dan sumbu $\mathrm{Y}$ menyatakan intensitas sinar $\mathrm{X}$ setelah melewati sampel serbuk dari MMT. Pada uji sampel serbuk bentonit menggunakan XRD ini, sudut pergerakan $2 \theta$ yang digunakan adalah $5^{\circ}-85^{\circ}$ dan puncak mulai muncul pada sudut ke $7,2^{\circ}-83^{\circ}$.

Hasil analisis bentonit Aceh Tamiang dengan metode XRD dapat dilihat pada Gambar 2 dan Tabel 1. Berdasarkan difraktogram pada Gambar 2 terlihat bahwa bentonit Aceh Tamiang menunjukkan puncak pada daerah $2 \theta=7,2^{\circ}, 14,5^{\circ}$, dan $19,8^{\circ}$ yang merupakan refleksi khas dari MMT [13][15][16][17][18][23]. Intensitas puncak pada $2 \theta$ $=7,2^{\circ}$ memberikan intensitas 70elative $100 \%$ dan refleksi $\mathrm{d}_{002}$ pada $2 \theta=19,8^{\circ}$ dengan intensitas $12,6 \%$ sesuai dengan standar pola XRD berdasarkan data Joint Committee on Powder Diffraction Standards (JCPDS) dengan No 96-901-0958 menandakan keberadaan MMT sebagai mineral penyusun utama dari sampel.

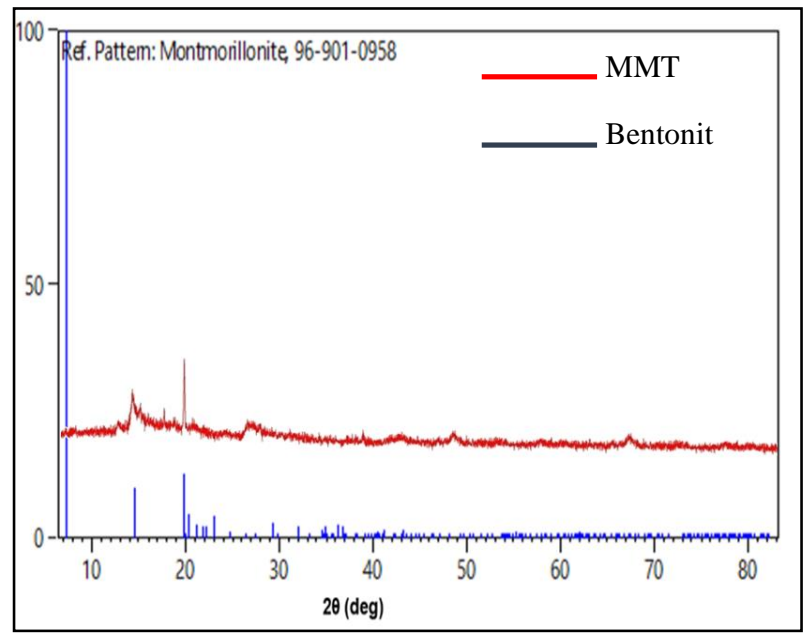

Gambar 2. Difraktogram Sinar-X Bentonit Aceh Tamiang.

Selain itu, pada difraktogram juga terdapat puncak pada daerah $2 \theta=23,0^{\circ}$ dan $2 \theta=29,3^{\circ}$ yang merupakan puncak refleksi kuarsa. Oleh karena itu, lempung bentonit juga tersusun dari mineral alam lainnya dalam jumlah yang sangat kecil yaitu mineral kuarsa sebagai impuritis. Mineral kuarsa ini merupakan komponen impuritis yang umumnya terdapat bersama-sama dengan mineral alam, yang tersusun atas $\mathrm{SiO}_{2}$ dengan tingkat intensitas refleksi yang tinggi. Berdasarkan hasil analisis XRD 
menunjukkan bahwa sampel bentonit Aceh Tamiang mengandung komponen utama montmorilonit dan komponen lainnya yaitu kuarsa.

Tabel 1. Daftar Puncak Dari MMT.

\begin{tabular}{cc}
\hline $2 \theta(\mathrm{deg})$ & Intensitas $(\%)$ \\
\hline 7,2 & 100 \\
14,5 & 10,1 \\
19,8 & 12,6 \\
23,0 & 4,4 \\
29,3 & 3,0 \\
\hline
\end{tabular}

\section{Karakterisasi Dengan PSA (Particle Size Analyzer)}

Sampel Nano-MMT telah berhasil disintesis dari bentonit Aceh Tamiang dengan alat High Energy Milling (HEM) selama 10 jam menghasilkan serbuk halus berwarna cokelat muda. Untuk membuktikan bahwa partikel montmorilonit yang disintesis telah berukuran nano maka dilakukan pengujian ukuran distribusi menggunakan PSA. PSA memperlihatkan hubungan antara ukuran partikel dengan jumlah partikel yang terdistribusi dalam sistem koloid. Secara rinci, ukuran partikel pada sampel bentonit Aceh Tamiang dapat ditunjukkan dengan Gambar 3 berikut ini.

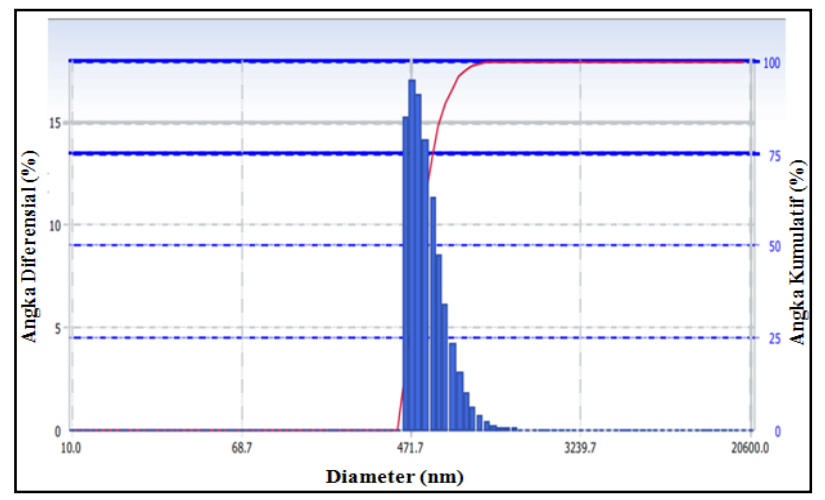

Gambar 3. Grafik distribusi ukuran partikel MMT Aceh Tamiang dengan PSA.

Berdasarkan Gambar 3 terlihat bahwa MMT Aceh Tamiang memiliki distribusi ukuran partikel paling tinggi $471,1 \mathrm{~nm}$ dan sudah berskala nano. Nano partikel dideskripsikan sebagai suatu partikel yang terdispersi pada ukuran nanometer atau skala per seribu mikron dan akan dikategorikan sebagai nano partikel jika memiliki ukuran 1-100 $\mathrm{nm}$ [19].

Analisis PSA menunjukkan adanya ukuran partikel dan distribusi ukuran partikel yang tidak merata, hal ini disebabkan oleh ketidakseimbangan tumbukan yang terjadi antara partikel yang berukuran kecil dengan partikel yang berukuran besar pada saat di milling dengan HEM. Resultan tumbukan yang berlangsung dari segala arah ini menyebabkan perubahan arah gerak partikel sehingga terjadi gerak zig-zag atau gerak Brown yang diinterpretasikan dalam bentuk ukuran partikel [20] dan luas permukaan yang tinggi [24]. Berdasarkan hasil analisis XRD dan PSA menunjukkan bahwa bentonit Aceh Tamiang mengandung montmorillonit sebagai komponen utama dan memiliki ukuran berskala Nano.

\section{Adsorpsi Minyak Nilam Menggunakan Nanomontmorilonite}

\section{Perubahan warna}

Pengamatan perubahan warna dilakukan secara visual yaitu menggunakan mata dengan jarak pandang kurang dari $18 \mathrm{~cm}$. Minyak nilam yang digunakan untuk penelitian ini berasal dari produsen penyulingan minyak nilam Aceh Tamiang. Warna sampel minyak nilam dari salah satu produsen $\mathrm{X}$ berwarna cokelat kehitaman sedangkan warna minyak nilam setelah penambahan Nano-MMT berubah menjadi cokelat kekuningan (jernih). Pengamatan warna pada minyak nilam Aceh Tamiang sebelum dan setelah diadsorpsi menggunakan Nano-MMT dapat dilihat pada Gambar 4 dan Tabel 2.

Tabel 2. Perubahan warna minyak nilam Aceh Tamiang sebelum dan setelah adsorpsi menggunakan nano-MMT.

\begin{tabular}{|c|c|c|}
\hline $\begin{array}{c}\text { Minyak Nilam } \\
(\mathrm{mL})\end{array}$ & $\begin{array}{c}\text { Nano-MMT } \\
(\mathrm{g})\end{array}$ & Warna \\
\hline 10 & 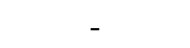 & Cokelat Kehitaman \\
\hline 10 & 0,5 & $\begin{array}{l}\text { Cokelat kemerahan } \\
\text { (gelap) }\end{array}$ \\
\hline 10 & 1 & $\begin{array}{l}\text { Cokelat kemerahan } \\
\text { (gelap) }\end{array}$ \\
\hline 10 & 1,5 & $\begin{array}{l}\text { Cokelat kemerahan } \\
\text { (jernih) }\end{array}$ \\
\hline 10 & 2 & Cokelat kemerahan \\
\hline 10 & 2,5 & $\begin{array}{l}\text { Cokelat kemerahan } \\
\text { pudar }\end{array}$ \\
\hline 10 & 3 & $\begin{array}{l}\text { Cokelat kekuningan } \\
\text { (jernih) }\end{array}$ \\
\hline
\end{tabular}

Gambar 4. Minyak Nilam (a) Sebelum Adsorpsi, (b) Minyak Nilam + 0,5 g Nano-MMT, (c) Minyak Nilam + $1 \mathrm{~g}$ Nano-MMT, (d) Minyak Nilam + 1,5 g Nano-MMT, (e) Minyak Nilam + 2 g Nano-MMT, (f) Minyak Nilam $+2,5$ g Nano-MMT, (g) Minyak Nilam + 3 g NanoMMT. 
Berdasarkan Tabel 2 dapat dilihat bahwa warna sampel minyak nilam setelah diadsorpsi menggunakan Nano-MMT mengalami perubahan dari cokelat kehitaman menjadi cokelat kemerahan hingga cokelat kekuningan, seiring dengan meningkatnya jumlah Nano-MMT yang ditambahkan ke dalam sampel minyak nilam. Hal ini disebabkan karena Nano-MMT akan mengadsorpsi komponen-komponen pengotor yang terdapat dalam minyak nilam [11]. Komponen pengotor yang terdapat pada minyak nilam dimungkinkan berasal dari wadah penyulingan yang terbuat dari logam besi. Semakin banyak jumlah Nano-MMT yang ditambahkan maka jumlah pengotor logam besi yang diadsorpsi oleh NanoMMT semakin banyak, sehingga menyebabkan warna minyak nilam semakin jernih. Berdasarkan hal tersebut maka dapat disimpulkan bahwa semakin banyak jumlah Nano-MMT yang ditambahkan ke dalam sampel minyak nilam maka warna yang dihasilkan semakin jernih.

Perubahan warna minyak nilam yang dihasilkan setelah adsorpsi menggunakan NanoMMT sudah sesuai dan memenuhi SNI 06-23852006 yaitu warna cokelat kemerahan sampai kuning muda. Proses perubahan warna dari cokelat kemerahan (gelap) menjadi cokelat kekuningan (jernih) terjadi dalam kurun waktu 1 jam hingga 2 jam. Hasil pengamatan warna minyak nilam menunjukkan bahwa Nano-MMT mampu mengadsorpsi kontaminan metalik dengan baik, seperti logam-logam berat yang menjadi pengotor di dalam minyak nilam [21].

\section{Kadar Patchouli Alcohol (PA)}

Hasil isolasi PA dan analisis GC-MS dinyatakan dalam dua parameter, yaitu waktu retensi (menit) dan konsentrasi (\%). Waktu retensi adalah angka spesifik dari masa interaksi antara molekul senyawa di dalam kolom kromatografi. Angka tersebut merupakan indikator kualitatif dari senyawa tersebut pada kondisi tertentu, konsentrasi menunjukkan tingkat kemurnian dari cuplikan yang dianalisis. Identifikasi jumlah dan kadar komponen-komponen dari tujuh sampel pengujian dengan konsentrasi perbandingan berbeda yang terdapat dalam minyak nilam dengan GC-MS disajikan pada Gambar 5.

Berdasarkan Gambar 5 dapat dilihat bahwa fraksi PA pada minyak nilam sebelum diadsorpsi terdapat pada waktu retensi 19,469 dengan kadar PA sebesar 7,74\% b/v. Puncak PA dalam kromatogram minyak nilam terletak pada akhir kromatogram. Hal ini menunjukkan bahwa PA merupakan komponen yang memiliki titik didih relative tinggi dalam minyak nilam selain senyawa golongan terpen. Titik didih yang relative tinggi tersebut dapat menerangkan mengapa minyak nilam memiliki sifat fixative, sifat inilah yang merupakan sifat unik dari minyak nilam. Sifat fixative adalah sifat yang dapat mengurangi penguapan dan mengikat aroma didalam minyak nilam, maka senyawa atsiri yang relative rendah jika dicampur dengan minyak nilam akan menaikkan titik didih campurannya, tingginya titik didih campuran ini membuat aroma pada minyak atsiri yang dicampurkan tidak mudah menguap sehingga dapat digunakan sebagai pengikat bau atau aroma pada produk-produk parfum atau kosmetik [11].

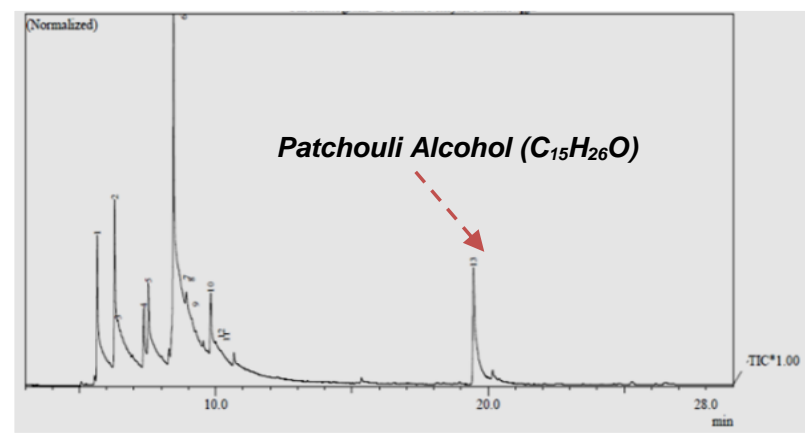

Gambar 5. Kromatogram GC-MS Minyak Nilam Sebelum Diadsorpsi.

Analisis PA juga dilakukan pada sampel minyak nilam yang ditambahkan Nano-MMT dengan variasi perbandingan adsorben Nano-MMT yaitu $0,5 \mathrm{~g} ; 1 \mathrm{~g} ; 1,5 \mathrm{~g} ; 2 \mathrm{~g} ; 2,5 \mathrm{~g}$; dan $3 \mathrm{~g}$. Hasil analisis PA dalam minyak nilam setelah ditambahkan Nano-MMT dengan berbagai variasi perbandingan ditunjukkan pada Gambar 5 berikut ini.

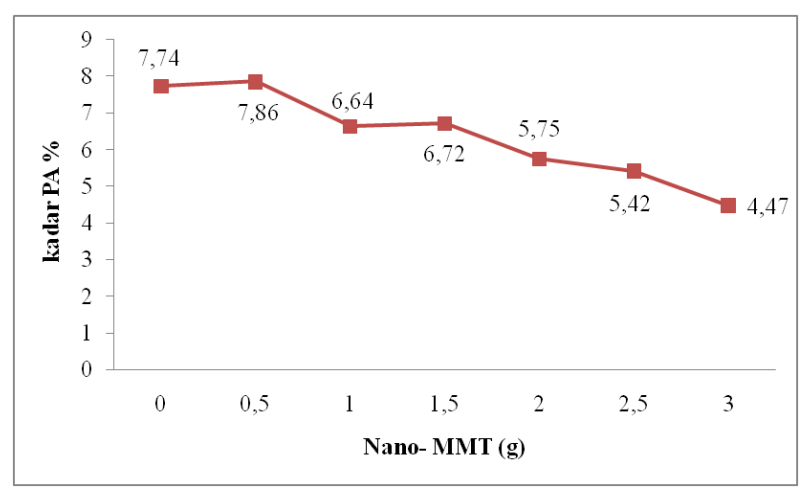

Gambar 6. Grafik kadar PA minyak nilam dengan variasi nano MMT.

Gambar 6 di atas menunjukkan bahwa kadar PA sebelum diadsorpsi dengan Nano-MMT sebesar $7,74 \% \mathrm{~b} / \mathrm{v}$ dan meningkat $0,12 \%$ menjadi $7,86 \% \mathrm{~b} / \mathrm{v}$ setelah penambahan Nano-MMT 0,5 g. Hal ini disebabkan oleh logam besi yang berada dalam minyak nilam teradsorpsi oleh Nano-MMT, sehingga mutu minyak nilam meningkat. Pada 
variasi penambahan $1 \mathrm{~g}$ Nano-MMT ke dalam minyak nilam, kadar PA mengalami penurunan sebesar $1,22 \%$ dari $7,86 \% \mathrm{~b} / \mathrm{v}$ menjadi $6,64 \% \mathrm{~b} / \mathrm{v}$. Kadar PA semakin menurun dengan semakin banyaknya jumlah Nano-MMT yang ditambahkan. PA merupakan komponen utama penyusun minyak nilam dan komponen yang paling penting dalam menentukan mutu minyak nilam. Penurunan kadar PA seiring dengan meningkatnya jumlah NanoMMT yang ditambahkan dimungkinkan terjadi kerusakan pada komponen kimia minyak nilam. Kerusakan ini terjadi dikarenakan proses hidrolisa, oksidasi resinifikasi dan tercampurnya minyak dengan bahan lain, pencemaran oleh wadah penyulingan minyak nilam, serta proses penyimpanan minyak nilam yang tidak tepat sehingga merusak komponen kimia dalam minyak nilam termasuk PA [22].

Selain itu, penurunan kadar PA terjadi dikarenakan luas permukaan Nano-MMT yang sangat besar sehingga tidak hanya mengadsorpsi logam besi tetapi juga mengadsorpsi PA di dalam minyak nilam. Berdasarkan hasil analisis tersebut maka dapat disimpulkan bahwa semakin banyak jumlah Nano-MMT yang ditambahkan ke dalam minyak nilam maka kadar PA semakin menurun.

Hasil analisis PA pada minyak nilam Aceh Tamiang setelah adsorpsi menggunakan NanoMMT menunjukkan bahwa kadar PA pada minyak nilam masih dibawah $30 \%$ sehingga belum sesuai dengan SNI 06-2385-2006 yaitu kadar PA minimal $30 \%$.

\section{SIMPULAN}

Kadar PA di dalam minyak nilam sebelum dan sesudah diadsorpsi dengan Nano-MMT belum sesuai dengan SNI 06-2385-2006 yaitu minimal $30 \%$. Pada penelitian ini kadar PA sebelum diadsorpsi $7,74 \% \mathrm{~b} / \mathrm{v}$, dan kadar PA setelah diadsorpsi berkisar antara 4,47\%-7,86\% b/v. Variasi perbandingan yang optimum dalam penelitian ini untuk minyak nilam: Nano-MMT adalah dengan perbandingan $0,5 \mathrm{~g}: 10 \mathrm{~mL}$.

\section{UCAPAN TERIMA KASIH}

Penulis berterima kasih kepada Kementerian Riset, Teknologi, dan Pendidikan Tinggi Republik Indonesia atas hibah yang diberikan melalui program Penelitian Dosen Pemula (PDP).

\section{REFERENSI}

[1] N.F.N. Wati, "Peningkatan Kualitas Minyak Nilam Melalui Proses Adsorpsi Menggunakan Adsorben y- Alumina dengan system Flow", Indonesian Journal Of Chemical Reaserch, vol. 1, no. 2, pp. 84-95, 2014.

[2] O. Sariadi, "Pemurnian Minyak Nilam Dengan Proses Adsorpsi Menggunakan Bentonit", Jurnal Teknologi, vol. 12, no. 2, pp. 100-104, 2012.

[3] Dinas Perkebunan Provinsi Jawa Timur, Budidaya Tanaman Nilam. Dinas Perkebunan Provinsi Jawa Timur Pengembangan Sarana Dan Prasarana Pembangunan Perkebunan, Jawa Timur, 2013.

[4] A. Idris, M.R. Jura, and I. Said, "Analisis Kualitas Minyak Nilam (Pogestemon cablin Benth) Produksi Kabupaten Boul", Jurnal Akademika Kimia, vol 3, no. 2, pp. 79-85, 2014.

[5] S. Shinta, "Potensi Minyak Atsiri Daun Nilam (Pogostemon cablin Benth), Daun Babadotan (Ageratum conyzoides L), Bunga Kenanga (Cananga odorata hook $\mathrm{F} \&$ Thoms), dan Daun Rosemarry (Rosmarinus officinalis L) Sebagai Repelan Terhadap Nyamuk Aedes Aegypti L.", Media Litbang Kesehatan, vol. 22, no. 2, pp. 61-69, 2012.

[6] Y. Aisyah, P. Hastuti, H. Sastrohamidjojo, and C. Hidayat, "Teknologi Pervaporasi Peningkatan Kadar Patchouli Alcohol Minyak Nilam Menggunakan Membran Selulosa Asetat", argiTECH, vol. 32, no. 2, pp. 207213, 2012.

[7] M.D. Supardan, A. Fatanen, and C. Erika, "Lemongras Oil Adsorption Using Bentonit", Jurnal Hasil Penelitian Industri, vol. 28, no. 2, pp. 88-94, 2015.

[8] T.T. Tee, L.T. Sin, R. Gobinath, S.T. Bee, D. Hui, A.R. Rahmat, and Q. Fang, "Investigation of Nano-Size montmorillonit on Enhancing Polyvinyl Alcohol- Starch Blends Prepared via Solution Cast Approach", Composite part B: Engineering, vol. 47, pp. 238-247, 2013.

[9] F. Susanti, T. Harmawan, and P. Wahyuningsih, "Pengaruh Interkalasi Mikro Montmorillonit Dengan Mikro Kitosan Sebagai Adsorben Untuk Meningkatkan Mutu Minyak Nilam", Jurnal Kimia dan Kemasan, vol. 43, no. 2, pp. 133-142, 2021.

[10] A. Allwar, F. Is, N. Fitri, and D. Rubiyanto, "Improvement of The Product and Quality of Pogostemon cablin Benth", EKSAKTA: Journal of Sciences and Data Analysis, vol. 14, no. 1, pp. 34-41, 2014. 
[11] I.S. Hardyanti, D. Septyaningsih, I. Nuraini, and A. P. Wibowo, "Analisis Kadar Patchouli Alcohol Menggunakan Gas Chromatography pada Pemurnian Minyak Nilam Menggunakan Adsorben Zeolit", Jurnal Rekayasa Teknologi Industri dan Informasi, vol. 2, no. 1, pp. 392-395, 2016.

[12] S. Ningsih, P. Wahyuningsih, and T. Harmawan, "Effectiveness Bleaching of Waste Cooking Oil Cleaning Using NanoMontmorillonite Adsorbent", Elkawnie: Journal of Islamic Science and Technology, vol. 7, no. 2, 2021.

[13] T. Harmawan, Y. Amri, and T.A. Fadly, "Isolation and Characterization Montmorillonite Nanoparticles of Aceh Tamiang Bentonite as Pathouli oil (Pogostemon cablin) Bleahing", Oriental Journal of Chemistry, vol. 35, no. 5, pp. 1535-1538, 2019.

[14] P. Wahyuningsih, T. Harmawan, R., Fajri, and R.A. Putra, "Synthesis of Biodiesel from Waste Cooking Oil Using the Sulfated Montmorillonite", In 2nd International Conference on Science, Technology, and Modern Society (ICSTMS 2020), Atlantis Press, pp. 28-31, 2021.

[15] P. Wahyuningsih and T. Harmawan, "Synthesis and Characteritation of AcidActivated Bentonite from Aceh Tamiang," In IOP Conference Series: Materials Siene and Engineering, vol. 725, no. 1, pp. 012050, 2020.

[16] L. Zhirong, M.A. Uddin, and S. Zhanxue, "FT-IR and XRD Analysis of Natural NaBentonite and $\mathrm{Cu}$ (II)-loaded-Na-Bentonite", Spectrochimica Acta Part A: Molecular and Biomolecular Spectroscopy, vol. 79, no. 5, pp. 1013-1016, 2011.

[17] J. da Silva Favero, V. dos Santos, V. WeissAngeli, L.B. Gomes, D.G. Veras, N. Dani, and C.P. Bergmann, "Evaluation and characterization of Melo Bentonite clay for cosmetic applications", Applied Clay Science, vol. 175, pp. 40-46, 2019.
[18] A. Kumar and P. Lingfa, "Sodium bentonite and kaolin clays: Comparative study on their FT-IR, XRF, and XRD", Materials Today: Proceedings, vol. 22, pp. 737-742, 2020.

[19] D.O.B. Apriandanu, S. Wahyuni, S. Hadisaputro, and H. Harjono, "Sintesis Nanopartikel Perak Menggunakan Metode Poliol Dengan Agen Stabilisator Polivinilalkohol (PVA)", Indonesian Journal of Mathematics and natural Sciences, vol. 36, no. 2, pp. 157-168, 2013.

[20] P. Morters and Y. Peres, Brownian Motion. Cambridge University Press. vol. 30, 2010.

[21] A. Fisli and S. Yusuf, "Sintesis Nanokomposit Magnetik Berbasis Bahan Alam Untuk Adsorben Thorium", Jurnal Sains Materi Indonesia, vol. 11, no. 2, pp. 93-98, 2010.

[22] S. Zaimah, "Pengujian Kualitas dan Komposisi Kimia Minyak Nilam (Pogostemon cablin Benth)", Indonesian Journal of Chemical Research, vol. 2, no. 1, pp. 1-9, 2014.

[23] M. Pentrák, V. Hronský, H. Pálková, P. Uhlík, P. Komadel, and J. Madejová, "Alteration of fine fraction of bentonite from Kopernica (Slovakia) under acid treatment: a combined XRD, FTIR, MAS NMR and AES study", Applied Clay Science, vol. 163, pp. 204-213, 2018.

[24] T. Harmawan, W. Ani, P. Andani, and T. A. Fadlly, "Production of Biodiesel Through Transesterification of Crude Palm Oil (CPO) Using Montmorillonite Nanoparticles (NanoMMT) as Heterogeneous Solid Catalyst", In 2nd International Conference on Science, Technology, and Modern Society (ICSTMS 2020), Atlantis Press, pp. 69-72, 2021. 